\title{
DISPUTE BETWEEN CHINESE AND KOREAN RESEARCHERS CONCERNING TERRITORIAL AFFILIATION OF THE KOGURYO KINGDOM IN THE LIGHT OF ARCHEOLOGICAL EXCAVATION
}

\author{
Magdalena Altyn \\ Adam Mickiewicz University \\ Faculty of History \\ ul. Umultowska 89D \\ 61-614 Poznan, Poland \\ m2008@interia.pl
}

\begin{abstract}
The aim of this article is to summarize knowledge regarding dispute about Koguryo territorial and historical affiliation, which occurred on the political and academic level. Between 37 BC and AD 668 ancient Kingdom of Koguryo embraced large area from central Manchuria to south of Seoul. After year 1945, when Korea regained independence, Korean researchers were able to begin their studies on the foundation of the national identity. According to the "Serial Research Project on the History and Current status of the Northeast Border Region" started in China in 2002, Koguryo was an ethnic system in one of the provinces in ancient China. Through this project Chinese historians and archaeologists wanted to incorporate history of Koguryo into the Chinese history, which was not acceptable to Korean researchers. Because of such approach from both sides to this issue, both countries were forced to use archeological excavations and obtained relics in order to show the connection between past and present in both, Koguryo-China and Koguryo- Korea history.
\end{abstract}

Key words: Koguryo, Northeast Project, Koguryo tombs, Chinese historiography, Koguryo Research Foundation, Kitora Ancient Tomb 


\title{
고고학적 발굴을 통한 고구려 왕국의 영토적 소속에 대한 한국과 중국학자들 간의 논쟁
}

개략: 기원전 37 년부터 기원 668 년까지 고대 고구려 왕국은 중앙 만주에서 서울의 남쪽에 이르는 광대한 지역을 차지하였다. 1945 년 해방 이후에 한국의 학자들은 민족의 정체성에 근거하여 그들의 연구를 시작하였다. 2002 년 중국에서 시작된 “동북쪽 변경지대의 역사와 현상에 관한 연구 프로젝트"에 따르면, 고구려는 고대 중국의 동북지역들 가운데 하나였다. 이 프로젝트를 통해 중국의 역사가들과 고고학자들은 중국의 역사에 고구려의 역사를 편입시키려 하였지만, 그것은 한국의 학자들에게는 용납될 수 없는 것이었다. 이 문제에 대한 양국의 그러한 접근방법에 따라 두 나라는 얻어진 고고학적 발굴물들과 고대 유적들을 고구려-중국 혹은 고구려-한국의 과거와 현재를 잇는 연결고리라는 것을 증명하려 했다.

키워드: 고구려, 동북공정, 고구려 고분, 중국 사료 편찬, 고구려연구재단, 기토라 고분

\section{SPÓR POMIĘDZY BADACZAMI CHIŃSKIMI I KOREAŃSKIMI DOTYCZĄCY TERYTORIALNEJ PRZYNALEŻNOŚCI KRÓLESTWA KOGURYO W ŚWIETLE ZNALEZISK ARCHEOLOGICZNYCH}

\begin{abstract}
Abstrakt: Celem tego artykułu jest streszczenie wiedzy o debacie dotyczącej przynależności terytorialnej i historycznej Koguryo, która wykształciła się na poziomie politycznym i akademickim. Pomiędzy 37 rokiem p.n.e. a 668 rokiem n.e. starożytne Królestwo Koguryo zajmowało ogromny obszar od środkowej Mandżurii do terenów na południe od Seulu. Po 1945 roku, kiedy Korea odzyskała niepodległość koreańscy badacze byli w stanie rozpocząć studia dotyczące ich tożsamości narodowej. Według "Serial Research Project on the History and Current status of the Northeast Border Region" rozpoczętego w Chinach w 2002 roku, Koguryo było jedynie systemem etnicznym wchodzącym w skład jednej z prowincji w starożytnych Chinach. Poprzez ten rozpoczęty projekt historycy oraz archeolodzy chińscy chcieli włączyć historię Koguryo do historii Chin, co oczywiście było nie do zaakceptowania przez naukowców koreańskich. $\mathrm{Z}$ powodu takiego podejścia obu stron do zaistniałego problemu, oba kraje zostały zmuszone do wykorzystania wykopalisk archeologicznych oraz uzyskanych zabytków w celu pokazania związków między przeszłością i teraźniejszością w przypadku historii na linii Koguryo-Chiny, jak i na linii Koguryo-Korea.
\end{abstract}

Słowa kluczowe: Koguryo, Northeast Project, Chiny, grobowce Koguryo, historiografia chińska, Koguryo Research Foundation, grobowiec Kitora 
The problem concerning Koguryo's territorial and historical connections has its start in the year 2001, when authorities in "Pyongyang applied to UNESCO to have tombs from ancient kingdom of Koguryo registered as North Korean's first "world heritage" sites" (Gries, 2005: 3). The beginning of controversies with China took place in 2002, when new research project- the Serial Research Project on the History and Current State of the Northeast Borderland (동북병강사현장계열연구공정)- has been started. This move allowed China to pursue their claims towards Koguryo historical affiliation. However Northeast Project ( 동북공정- this is the shorter form for Chinese project) was not just an academic issue, but it also carried large-scale political consequences (Kim: 21). With time the number of Chinese claims regarding Koguryo matter increased largely in number (Yonson, 2006-a). This move created not only political pressure between Korea and China, but also brought out huge emotional reaction among Koreans (Seo, 2008: 40).

As Gries explains, situation concerning "world heritage" sites was solved by UNESCO on July $1^{\text {st }} 2004$. However, despite the fact that China's sites on the World Heritage List has been named as "Capital Cities and Tombs of the Ancient Koguryo Kingdom", in Chinese media they were still functioning as "China's Koguryo". Not long after that South Koreans came to know about another controversial move from the Chinese side, which was the removal of "Koguryo from the summary of Korean history on the website of China's Ministry of Foreign Affairs" (Gries, 2005: 3). Continuation of such approach was visible in the actions of the Center of China's Borderland History and Geography Research, where researchers who favored government policy, described Koguryo as a "provincial" vassal kingdom under the suzerainty of China" and not as the independent Korean state which was strong enough to fight back China's power (Choe, 2006). According to Lankov such situation led to a diplomatic crisis as South Korean diplomats demanded clarification of Chinese actions. According to the official Chinese explanation Northeast History Project was something, which should not be connected in any way with political directions taken by the country. In August 2004 both sides agreed to leave the Koguryo 
problem to the historians (Lankov, 2006.) Professor Ahn Byung Woo ( South Korea's Hanshin University) fears that the Northeast Asian Project, which now is focused on Koguryo history, in real targets not only Koguryo's historical heritage, but also can be used for pursuing claims towards Manchuria and even northern parts of Korean peninsula (Gries, 2005: 5-15).

\section{Northeast Asian History Project}

As Park states "the Northeast Asian Project is a large scale academic project designed to study the history and present state of China's border areas". The main goal of that project was to prove that the Northeast regions, especially territories where Koguryo, Old Choson, Puyo, Parhae were located, belonged to China in both historical and cultural way (2004: 19). Chinese Academy of Social Sciences [zhongguo shehui kexue yuan,中国社会科学院] (CASS) fully directed all associated with the project actions ( Washburn, 2012: 131). Chinese provinces: Liaoning, Jilin and Heilung Kiang, as being the ones most interested in Northeast Project research findings, due to their location, declared their full support for launched process (Park, 2004: 19).

Constitution from 1954 clearly shows China's reasoning for the Northeast Project. According to Kim, government wanted to promote the "united multiethnic state theory", and that is why all China's border provinces, due to being populated by ethnic minorities, needed to be associated more closely with China. At the same time the aim was to show their distinction from all neighboring countries, so that there would be no doubts as to where culturally, politically and geographically they belong (Kim: 21-22 ). As Park stated, on the territory of China can be distinguished 55 ethnical minorities, from which ethnical Koreans were showing the strongest connection with their origins. Therefore, to overpower the "growing nationalistic tendencies", which started to be heard more loudly among them, Northeast History Project has been started ( 2004: 19-20). 
2. Chinese approach to Koguryo's history

According to Mark Byington, analysis of articles wrote on the subject of Koguryo in Chinese academic journals since 1950 reveals some interesting information. In the period between 1950 and 1982 the problem of Koguryo's historical affiliation didn't appear in articles published in history and archaeology journals. What's more there was no question concerning Koguryo's place in Chinese historiography, on the contrary it seems that there was more statements about connecting Koguryo with Korean history or at least showing its autonomy from China. However, everything changes in 1983, when the majority of articles associated Koguryo with Chinese history. This way of treating Koguryo by connecting it with China reached the highest point in 1997 ( 2002:14).

To emphasize Chinese position towards Koguryo, Lee presents opinion of Chinese historian Sun Jinji, who in the year 1986 argued that "the people of Buyeo and Koguryo had the same lineage as the Chinese in the Northeast region, while the Korean people were a part of the Silla lineage" . This statement meant that author was considering that Koguryo's history did not have any connection with the period in which Three Kingdoms emerged and existed (Lee, 2005: 189). According to Yohnson, Chinese scholars, in Northeast Project, based their demands for Koguryo's historical heritage on two main points:

- the first is that Koguryo had its roots in Han Chinese commandery of Xuantu', therefore its connections with China are much more justified than those with Korea;

- the second one is that according to Ma Dazheng's words Koguryo was "an influential ethnic group in China's border area in northeastern China between the Western Han Dynasty (206 BC- 24 AD) and the Tang Dynasty (AD 618-907)" (2006-a: 1-2). 


\section{Korean response to Northeast Project}

New year- 2003, brought new factor in the "Koguryo controversy" case, in which an application to UNESCO has been sent by the Chinese government. As Chen showed, China wanted to "register the Capital Cities and Tombs of the Ancient Koguryo Kingdom located on its territory as a World Heritage Sites". In December of the same year, due to all actions taken by Chinese side, the South Korean government found itself in a position when a report in which arguments against connecting Koguryo with Chinese history were presented, as well as guidelines to Korean civil society groups regarding taking and responding to Chinese claims, needed to be published (Chen, 2012: 227-241).

Scotfield agrees that according to Korean academics Koguryo kingdom, due to its strength, played the leading role in the Three Kingdoms period, and until the late $7^{\text {th }}$ century occupied north part of the Korean peninsula together with the vast Manchurian region. From the beginning of its existence, and especially after strengthening of its position by the $4^{\text {th }}$ century, Koguryo was able to successfully clash with its southern rivals, as well as its biggest neighbor- China (Scofield, 2003).

According to Shin, whose opinion was mentioned by Washburn, Koguryo's importance is based on the fact that it was not just one of the small proto- Korean kingdoms, but the one which was the most genuine. After its establishment and years of development, Koguryo gained position, which made it possible to influence various states, which in the end were able to unite the whole peninsula (Washburn, 2012: 138). Choe Kwang-sik, who according to Yonson "was a leading South Korean historian and protester in the Koguryo affair", shows examples against Chinese changes concerning Koguryo's territorial affiliation:

1. adding Koguryo's history to the history of China would mean taking 700 years from Korean history,

2. Koreans would lose the "historical pillar" so much important in the process of creating their own identity, 
3. changing the borders by taking Korea's territory located north to the Han River (Yonson, 2006-a: 3; 2006-b).

Two years after the beginning of the conflict between China and Korea, on 1st of March 2004, the Koguryo Research Foundation had been established by South Korean government. Its aim was to promote materials supporting arguments on the subject of Koguryo's historical affiliation with Korea (Lee, 2011: 162). Main goal of the Foundation, which is an scholarly institution sponsoring study and all kinds of research proposals on subjects connected with ancient Korean and East Asian History, is supporting projects, which leads to "restoring historical truths of Korea and its surrounding regions". Foundation is an answer to all actions taken by the Chinese government directed against Koguryo's historical affiliation to Korea (Koguryo Research Foundation, 2006).

"Koguryo controversy" became the most important reason for both South and North Koreans to join forces in order to conduct research on Koguryo burial mounds. During the academic conference on Koguryo history and culture organized by Koguryo Research Foundation and the North Korean Academy of Social Science in Vladivostok, both sides agreed to conducting research programs, which were a kind of response to China's registration of Koguryo material findings in Jian as UNESCO World Heritage Sites, as well as to all attempts made by China connected with the Koguryo history, focused on trying to assimilate its history with China's history (The Chosunilbo, 2005).

4. Northeast Project and archaeological findings

According to Hobsbawn, "archeology is often associated with patriotism in both the "periphery" as well as the "core"". All Koguryo remains are playing a very important role in the battle between China 
and Korea regarding its territorial and historical legacy, what is highly connected with the crucial role of inheritance. Ancestral states are the most important aspects of cultural supremacy among different nations, what also describes overall view on Koguryo's position in Korea's history (Yonson, 2006-a: 6; 2006-b).

Researchers say that in the areas of Jian, China, Pyeongyang and Anak in North Korea they can identify 13000 Koguryo ancient tombs. However, finding mural paintings among those tombs is not an easy thing. Therefore, there are only 20 such tombs on the territory of Ji'an, China and significantly more -80 on the territory of North Korea (Kim Lena, 2004: 5). Kang Hyun-sook, whose view was presented by Yonson, said that Koguryo tombs with murals definitely were not just simple reproduction of their prototypes in China. What's more, due to archeological findings from the territory of Japan, we can say that they also influenced Japan's funerary culture. She also concluded that all evidences of Koguryo's influence seen not only in Japan but also on the Korean peninsula shows how powerful position it had in the region from the cultural point of view. Therefore, from this perspective all archaeological data, which can be linked with Koguryo culture, should be treated as symbols of heritage and domination of Koguryo culture (Yonso, 2006-a: 5, 2006-b).

According to Chon, on 6th of March Japanese archeologists informed about making a great discovery in the Kitora Ancient Tomb in Asukamura, Nara prefecture. This discovery had been made after completing the investigation of, probably seventh or eighth century mural, where in the burial chamber made of stone researchers found two sacred creatures, and on the ceiling an astronomical chart with the presentation of the sun and the moon. Those mythological beasts are something which were never discovered on the territory of Japan, however on the Korean peninsula they are known very well. Further he said that the one on the east wall is known as "Chongryung" or a blue dragon and the one on the west wall is called "Paekho" or a white tiger. Those two creatures symbolize two of the four directions of north, south, east and west. They are typical decoration motif found in Koguryo murals, but is something unknown in China. Chon said that "Hyunтu - a snake crossed with a tortoise" -third presentation situated on the north wall, has been discovered in 1984, before 
Chungryung and Paekho's discovery. However, last "god named "Chujak" or red sparrow which should be present on the south wall has not been found yet". The discovery in the Kitora tomb surprised everyone with the "accuracy of the astronomical chart, especially putting polestar in the middle and surrounding it with more than 1,000 other stars thought to include the Milky Way". What's more, Chon presents the assumption, which is also represented by other scholars and which says that gold and silver stars connected with each other by red lines were supposed to create a constellation. Two other elements- gold and silver circles- are treated by researchers as sun and moon. Because of such a big similarities between Kitora Tomb murals and Koguryo mural paintings, it is believed that creators of Kitora Tomb must have been associated with Koguryo people, as Chon said probably they were educated in the painting techniques used on the Koguryo territory. All materials coming form that tomb imply that people who built and decorated it must have had great astronomical knowledge (Chon, 1997). According to Dr. Jeon mentioned by Ho, "Koguryo tomb murals were introduced to Japan by monks and craftsmen of Koguryo. Murals of Kitora tombs may have been drawn by immigrants of Koguryo and Japanese painters". Those findings are a very good example showing how close were the relations between those two civilizations at the time (Ho, 2011).

In 2007 the Northeast Asian History Project was finished, however the discussion which had been brought up in the year 2002 did not just disappear. One of the South Korea's newspapersHankyoreh, informed its readers about conducted "closed research" on an commemorative stone with inscriptions, which could be dated to the fifth century. "Concerns are being raised," the Hankyoreh piece noted, "that with key figures from the Northeast Project taking part in the research, it is very likely that China will use the results of the study to reinforce its argument that Koguryo belongs to China" (Washburn, 2012: 132). This stele was discovered in Chinese northeastern province -Jilin, therefore it seemed to be obvious, that one of the researchers in the research team was Wei Cuncheng, professor at Jilin University. He played a very important role in the Northeast Project, and according to Park we can even say that he was 
the most influential researcher, who was also one of the scholars delegated to represent project's research goals and conclusions within the expert committee . In the subject of the history of Koguryo and Balhae and the southern and northern dynasties period in China he is thought to be in top of the leading scholars. This Koguryo stele, which was probably constructed around the year 414, was actually discovered on July 2012 in Maxian, but the announcement have been made much later, with the start of a new 2013 year. This was the third discovery of a stele, which disclosed information important for Koguryo's history. Before this finding there were discovered two other steles- "the Gwanggaeto Stele and the Koguryo Stele in Chungju" (Park, 2013).

\section{Conclusion}

According to Mark Byington, Chinese claims have no historical basis, however Chinese scholars and politicians have some compelling, in their opinion, reasons for sustaining them. Reactions from Korean government and all scholars involved in research on Korean ancient history, especially Koguryo history are completely understandable, however in his opinion most Koreans treat Chinese claims as just a beginning of their aggression, aggression which can change with time into an active one. Therefore, to understand it more, they should try to see them in a broader perspective. That way they would understand that this is just the most recent phase of a progressing process that can be dated back to the early twentieth century, and which shows development in a new manner since 1993 (Byington, 2004).

Other Korea scholar Andrei Lankov said:

"However, the entire dispute represents the same case of retroprojection of modern identities. The real-life Koguryoans would be seriously surprised or even offended had they learned that in future they would be perceived as members of the same community as their bitter enemies from Silla. Describing Koguryo as "Chinese" or 
"Korean" is as misleading as, say, describing medieval Brittany as "French" or "English" or "Irish"" (Lankov, 2006).

According to Yonson "the whole debate is heavily based on the empiricist paradigm". Both sides claim to use scientific or academic methods to research the history of Koguryo. They use methods which are given by archeology and by history to bring not complete, but just fragmentary evidences from both of them. As a result Yonson said that we can see that interpretations of same archaeological and historical findings presented on both sides are opposing each other, and what might be more significant they are heavily influenced by political agendas. While observing the whole debate we can be sure of one thing, which is the fact that Koguryo with its history, territory and symbolism is equally important for the accuracy of China and Korea. Because of all those reasons, which are inseparably connected with the demanding of gaining more historically legitimized power, ancient history of Koguryo started to be used for both interested sides as theoretical base (Yonson, 2006-a: 7, 2006-b).

In the opinion of Peter Hays Gries, with whom I agree there can be a very dangerous situation for Chinese and Korean security policies, if both countries will allow the Koguryo controversy to develop into a bigger and more important issue. There is a risk in getting involved into some kind of identity competition, which can lead to "existential combat", where both sides will constantly try to delegitimize each other in historical matter (Gries, 2005: 14).

\section{References}

Byington, Mark. 2002. The Creation of an Ancient Minority Nationality: Koguryo in Chinese Historiography, 14. Harvard University. 
http://congress.aks.ac.kr/korean/files/2_1358750029.pdf (accessed May 24, 2014).

Byington, Mark. 2004. The War of Words Between South Korea and China Over An Ancient Kingdom: Why Both Sides Are Misguided,( October 9), http://historynewsnetwork.org/article/7077\#sthash.rsCQE73r. dpuf (accessed May 25, 2014).

Chen, Dingding. 2012. Domestic Politics, National Identity, and International Conflict: the case of the Koguryo controversy. Journal of Contemporary China 21 (74) : 227-241.

Choe, Sang-Hun. 2006. Tussle over a vanished kingdom - Asia Pacific - International Herald Tribune. The New York Times, October

http://www.nytimes.com/2006/10/12/world/asia/12ihthistory.3134615.html?pagewanted=all\&_r=2\&_(accessed May 24, 2014).

Chon, Ho Chon. 1997. Kitora Tomb Originates in Koguryo Murals. http://www1.korea-np.co.jp/pk/035th_issue/98032502.htm (accessed May 22, 2014).

Gries, Peter Hays. 2005. The Koguryo Controversy, National Identity, and Sino-Korean Relations Today; East Asia, http://www.ou.edu/uschina/gries/articles/texts/Gries2005Kogu ryoEAIQ.pdf (accessed May 20, 2014)

Ho, Tae Jeon. 2011. lecture on Takamatsu and Kitora Tombs of Japan, May 19, in Portland State University. H-Japan, April 28, 2011 http://h-net.msu.edu/cgi-bin/logbrowse.pl?trx=vx\&list=hjapan \&month $=1104 \&$ week $=e \& m s g=x C 5 N X 3 y t 4 F C w f O u d r k$ ESUw\&user $=\& p w=($ accessed May 22, 2014).

Kim, Lena (ed.). 2004. World Cultural Heritage. Koguryo Tomb Murals, ICOMOS- Korea, Cultural Properties Administration https://books.google.pl/books?id=xRGBgAAQBAJ\&pg=PA105\&lpg=PA105\&dq=\%E2\%80\%9C Koguryo+Tombs:+Past+and+Present $\%$ E2\% 80\%9D\&source $=$ bl\&ots=QHYNV2sMkO\&sig=LQSoFhM8Ts9eH1i q4g8uou UIIk\&hl=pl\&sa=X\&ved=0ahUKEwjE27Hv0ofRAhUGfiwK HSAaBIEQ6AEIKTAC\#v=onepage $\& \mathrm{q}=\% \mathrm{E} 2 \% 80 \% 9 \mathrm{CKogur}$ 
yo\%20Tombs\%3A\%20Past\%20and\%20Present\%E2\%80\%9D $\& \mathrm{f}=$ false $($ accessed May 21, 2014)

Kim, Christopher. F. 5,000 years of History, Archeology, Nationalism, and Politics in Korea. Brown University. https://www.brown.edu/Departments/Joukowsky_Institute/un dergrad/prizes/Kim2013.pdf (accessed May 20, 2014)

Lankov, Andrei. 2006. "China and Korea can't escape their pasts. History News Network (September 16), http://historynewsnetwork.org/article/30047\#sthash.HlUqfuR Z.dpuf (accessed May 21, 2014).

Lee, Soon Keun . 2005. On the Historical Succession of Goguryeo in Northeast Asia. Korea Journal, 45 (1): 172-201.

Park, Kyeong-chul. 2004. History of Koguryo and China's Northeast Project, ed. Choi Deok-soo. International Journal of Korean History, 6. Center for Korean History, Institute of Korean Culture.

Park, Min-hee. 2013. China conducting closed research into ancient Korean dynasty. The hankyoreh ( January 26), http://english.hani.co.kr/arti/english edition/e international/5 71401.html (accessed May 19, 2014).

Scofield, David. 2003. Northeast Asia's Intra-mural Mural Wars. Asia Times Online CO.

http://www.atimes.com/atimes/Korea/EL23Dg01.html (accessed May 23, 2014).

Seo, Jungmin. 2008. The Politics of Historiography in China: Contextualizing the Koguryo Controversy. Asian Perspective, $32(3): 39-58$.

Taylor, Washburn. 2012. Goguryeo Ghosts: China's History Dilemma and the Future of Sino-Korean Relations. SAIS U.S.-Korea Yearbook. http://uskoreainstitute.org/wpcontent/uploads/2014/04/Washburn_YB2012.pdf ( accessed May 20, 2014)

World Heritage List. http://whc.unesco.org/pg.cfm?cid=31 (accessed May 24, 2014).

Yonson, Ahn. 2006-a. Competing Nationalism: The mobilization of history and archeology in the Korea-China wars over 
Magdalena AŁTYN: Dispute Between Chinese and Korean ...

Koguryo/Gaogouli. The Asia-Pacific Journal: Japan Focus, http://japanfocus.org/-Yonson-Ahn/1837 (accessed May 22, 2014).

Yonson, Ahn. 2006-b. The Korea-China Textbook War-What's It All About? . History News Network (September 13), http://hnn.us/articles/21617.html (accessed May 22, 2014).

2005. Two Koreas in Joint Response to China's Koguryo Distortions. The Chosunilbo, May 07. http://english.chosun.com/site/data/html_dir/2005/03/07/2005 030761036.html (accessed May 23, 2014).

2006 Koguryo Research Foundation Visiting International Scholar Research Fellowship Program (February 01), http://www.international.ucla.edu/asia/article/38282 (accessed May 24, 2014). 